\title{
Михалюк А.M.,
}

старша викладачка кафедри теорії та історії педагогіки

Педагогічного інституту Київського університету імені Бориса Грінченка,

кандидатка педагогічних наук

ORCIDiD0000-0003-0452-1260

a.mykhaliuk@kubg.edu.ua

УДК 378.091.33-027.22

DOI: 10.28925/2311-2409.2020.33.9

\section{ВИКОРИСТАННЯ ІНТЕРАКТИВНИХ МЕТОДІВ НАВЧАННЯ В ПРОЦЕСІ ПІДГОТОВКИ МАЙБУТНІХ ПЕДАГОГІВ}

\begin{abstract}
У статті висвітлено сутність інтерактивних методів навчання та аргументовано переваги їх застосування в освітньому процесі закладів вищої освіти. Виявлено особливості використання інтерактивних методів навчання у процесі підготовки майбутніх педагогів. Подано характеристику окремих методів інтерактивного навчання, розкрито значення їх використання в процесі формування особистісних та професійних якостей майбутніх педагогів.
\end{abstract}

Ключові слова: інтерактивне навчання; методи інтерактивного навчання; підготовка майбутніх педагогів.

(с) Михалюк А.М., 2020

( ) Київський університет імені Бориса Грінченка, 2020

Вступ. Інтеграція української спільноти до світового соціокультурного простору передбачає створення у закладах вищої освіти моделі навчання з позицій загальноєвропейських стандартів. Прагнення до визнання дипломів на європейських освітніх теренах зумовлює оновлення і модернізацію вищої педагогічної освіти та впровадження інновацій у підготовку педагогічних кадрів. У світлі вищезазначеного сучасний освітній процес у закладах вищої освіти повинен бути спрямований не лише на професійне, а й на особистісне зростання студентів. Для реалізації особистісного потенціалу кожного студента в процесі навчання виникає необхідність у створенні умов для формування таких якостей особистості, як мобільність, уміння інтегруватись у динамічне суспільство, критичність мислення, уміння генерувати нові ідеї, здатність приймати нестандартні рішення й нести за них відповідальність, комунікативні уміння, навички роботи в команді, уміння моделювати навчальні та виховні ситуації тощо. Вирішенню таких завдань сприяє застосування інтерактивних методів навчання.

Мета статті - 3'ясувати сутність інтерактивних методів навчання, висвітлити значущість даних методів навчання в процесі підготовки педагога у закладах вищої освіти.

Аналіз праць вітчизняних і зарубіжних науковців. Проблема підготовки вчителя постійно перебуває в центрі уваги науковців різних галузей знань. Вагомий внесок у вирішення означеної проблеми належить зарубіжним та українським педагогам, зокрема Г. Ващенку, В. Сухомлинському,
М. Стельмаховичу та ін. На з'ясування сучасних умов розбудови педагогічної освіти зорієнтовано роботи таких знаних учених, як Н. Бібік, О. Дубасенюк, І. Зязюн, В. Моляко, Н. Ничкало, О. Пехота, О. Савченко, О. Сухомлинська та інших. Безперечно є багато наукових здобутків, які обгрунтовують доцільність застосування інтерактивних методів для підвищення ефективності процесу навчання. До таких належать праці О. Коротаєва, Г. Мітіна, Л. Пироженко, О. Пометун, С. Сисоєвої, М. Скрипник, Г. Шевченко та інших.

Викладення основного матеріалу. У сучасній теорії та практиці накопичено багатий досвід щодо розуміння поняття «інтерактив». 3 довідково-енциклопедичних джерел відомо, що слово «інтеракція» (дослівно «взаємодія») походить від латинського, французького та англійського «interaction», складовими елементами якого $€$ префікс «inter», що означає «між», «посеред»; та корінь «асtion» - дія, діяльність. Таким чином, інтерактивний - здатний до взаємодії, діалогу (Кравчина, 1999).

Так, дослідниця О. Пометун вважає, що сутність освітнього процесу полягає у взаємодії того, хто навчає, і тих, хто навчається, тобто і викладач, і студенти $є$ суб'єктами освітнього процесу. Взаємодія - це безпосередня міжособистісна комунікація, особливою рисою якої $є$ здатність людини уявляти себе на місці свого партнера по спілкуванню, пізнавати, як він чи вона реагує на перебіг спілкування i, відповідно, аналізувати ситуацію, приймати необхідні рішення. У струк- 
турі взаємодії викладача та студента О. Пометун виокремлює такі елементи: 1) перебування учасників взаємодії у єдиному просторі і часі, встановлення безпосереднього міжособистісного контакту; 2) визначення мети й очікуваних результатів спільної діяльності; 3) планування, контроль, корекція спільних дій та їх координування; 4) рівний розподіл спільної праці між всіма учасниками; 5) встановлення суб'єкт-суб'єктних взаємовідносин (Пометун, 2007).

В дослідженні С. Сисоєвої зазначається, що інтерактивне навчання характеризує такий процес навчання, який побудований на взаємодії студента 3 навчальним оточенням, навчальним середовищем; грунтується на психології людських взаємин і взаємодій; сутність якого полягає в організації спільного процесу пізнання, коли знання здобуваються в спільній діяльності через діалог, полілог студентів між собою й викладачем. Інтерактивне навчання студентів здійснюється з урахуванням їх інтересів і запитів, життєвого і професійного досвіду, у формах партнерської взаємодії всіх суб'єктів навчального процесу. Таким чином, при інтерактивному навчанні всі учасники освітнього процесу взаємодіють між собою, обмінюються інформацією, спільно вирішують проблеми, моделюють ситуації, оцінюють дії колег і свою власну поведінку, занурюються у реальну атмосферу ділового співробітництва 3 розв'язання низки проблем відповідно до їх інтересів, потреб і запитів. При цьому відбувається постійна зміна видів навчальної діяльності: гри, дискусії, робота в малих групах, мінілекції тощо (Сисоєва, 2011, с. 5).

Переконливою є думка М. Скрипник про те, що інтерактивні методи навчання є системою способів діалогічної взаємодії суб’єктів навчання, що спрямовані на осмислення змісту діалогу. В основу класифікації інтерактивних методів автор пропонує покласти ряд функцій педагогічного спілкування (діалогу), визначених дослідником О. Киричуком, а саме: інформаційна, пізнавальна, мотиваційна, регулятивна. Відтак, інтерактивні методи навчання M. Скрипник поділяє на інформаційні, пізнавальні, мотиваційні і регулятивні інтерактивні методи (Скрипник, 2005).

Таким чином, із вищезазначеного випливає, що сутність інтерактивного навчання полягає у взаємонавчанні, груповій формі організації освітнього процесу із реалізацією активних групових методів навчання для вирішення дидактичних завдань. У такій освітній взаємодії викладач виконує функції помічника в роботі, консультанта, організатора та стає одним із джерел інформації. Особливого значення набуває партнерська взаємодія між студентами і викладачем, коли учасники освітнього процесу виступають рівними суб'єктами навчання, та відсутнє домінування будь-кого із них. Під час такого діа- логічного навчання у студентів формується здатність мислити критично, розвивається вміння розв'язувати складні проблеми на основі аналізу обставин і відповідної інформації, з'являється потреба брати участь у різних дискусіях, формується здатність приймати зважені рішення та спілкуватись з іншими людьми.

У сучасній практиці підготовки майбутніх педагогів досить ефективно використовуються різні способи навчання у співробітництві, які сприяють залученню студентів до інтерактивної діяльності на заняттях. Розглянемо сутність найпоширеніших інтерактивних методів навчання. Робота в парах - ефективний метод, що передбачає обмін ідеями з партнером та подальше озвучення своїх думок перед аудиторією. Означений метод сприяє формуванню навичок співробітництва, оволодінню вміннями висловлюватись та активно слухати. Для актуалізації опорних знань ефективним є використання методу «Мікрофон», який надає можливість кожному студенту сказати щось швидко, по черзі, відповідаючи на запитання або висловлюючи свою думку чи позицію. Основними вимогами до використання методу «Мікрофон» визначено такі як: говорити має тільки той, у кого «символічний» мікрофон, відповіді не коментуються і не оцінюються, коли хтось висловлюється, інші не можуть говорити. Такий вид роботи дає можливість активізувати розумову діяльність студентів та налаштовує їх на сприймання та активну дискусію на занятті. Чільне місце в навчальному процесі вищої школи посідає такий метод колективного обговорення, як «Мозковий итурм». Ефективність даного методу досягається шляхом вільного вираження думок усіх учасників і допомагає знаходити кілька рішень за певною темою. Метод «Карусель» найбільш ефективний для одночасного включення всіх учасників освітнього процесу в активну роботу з різними партнерами для обговорення дискусійних питань. Метод «Навчаючи - учусь» дає можливість студентам передавати свої знання своїм одногрупникам. Використання цього методу дає можливість студентам узагальнювати поняття і факти, сприяє виникненню запитань та підвищує інтерес до навчання. Також важливим способом здійснення інтерактивного навчання є метод проектів, що зумовлює набуття і застосування студентами практичних умінь та навичок. У проектній роботі студенти залучаються в створену педагогом пошукову навчально-пізнавальну діяльність. Використання методу проектів в навчальній діяльності студентів формує у них креативність, стимулює інтелектуальну активність, розвиває комунікативні вміння, формує здатність працювати в команді, розвиває інформаційно-комунікаційні навички. Важливим засобом пізнавальної діяльності майбутніх фахівців виступає дискусія, яка передбачає широке публічне обговорення 
якогось спірного питання. Використання даного методу у навчальному процесі здійснюється в певній послідовності. Перш за все формулюється конкретне дискусійне питання, на яке немає однозначної відповіді й допускає різні варіанти вирішення. Під час такого обговорення виявляються різні позиції, а емоційно-інтелектуальний поштовх пробуджує бажання активно мислити. Усі висловлювання повинні супроводжуватись аргументацією. Дискусія може завершитися як консенсусом (прийняттям узгодженого рішення), так і збереженням існуючих розбіжностей між іiі учасниками. Використання в навчальному процесі майбутніх педагогів методу дискусії сприяє розвитку критичного мислення, дає можливість визначити власну позицію, формує навички аргументації та відстоювання своєї думки, навчає чути й розуміти співрозмовника.
Висновки. Отже, впровадження у закладах вищої освіти моделі навчання з позицій загальноєвропейських стандартів зумовлює активне застосування технологій інтерактивного навчання, що сприяє підвищенню якості підготовки майбутніх педагогів. Використання інтерактивних методів сприяє побудові партнерських взаємовідносин між усіма учасниками освітнього процесу, спонукає їх до постійної творчості й самовдосконалення. У такій взаємодії викладач набуває рис фасилітатора, організатора самостійної, навчально-пізнавальної, комунікативної, творчої діяльності студентів. Вищезазначене не вичерпує всіх аспектів порушеної проблеми і потребує подальших науково-методичних розробок щодо впровадження у практику підготовки майбутніх педагогів сучасних інноваційних освітніх технологій.

\section{ДЖЕРЕЛА}

1. Активні та інтерактивні методи навчання / уклад. О.С. Кравчина. Київ : УІ ППОАН України, 1999. 123 с.

2. Підласий І.П. Практична педагогіка або три технології : інтерактивний підручник для педагогів ринкової системи освіти. К.: Слово, 2004. 616 с.

3. Пометун O.I. Технологія інтерактивного навчання як інноваційне педагогічне явище. Рідна Школа. Київ: Рідна Школа, 2007. № 5. С. 46-49.

4. Сисоєва С.О. Інтерактивне навчання дорослих у системі післядипломної педагогічної освіти. Наукові праці. Педагогіка. Випуск 146. том 158. Миколаїв, 2011. С. 5-10.

5. Скрипник M.І. Інтерактивне навчання: основні поняття. Ігри дорослих. Інтерактивні методи навчання. Бібліотека. Київ : Ред. загальнопед. газет, 2005. С. 30—44.

\section{REFERENCES}

1. Aktyvni ta interaktyvni metody navchannia [Active and interactive teaching methods] / uklad. O.S. Kravchyna. Kyi : UI PPOAN Ukrainy, 1999. 123 s. (in Ukrainian)

2. Pidlasy, I.P. (2004). Praktychna pedahohika abo try tekhnolohii [Practical pedagogy or three technologies]: interaktyvnyi pidruchnyk dlia pedahohiv rynkovoi systemy osvity. K.: Slovo, 2004. 616 s. (in Ukrainian)

3. Pometun, O.I. (2007). Tekhnolohiia interaktyvnoho navchannia yak innovatsiine pedahohichne yavyshche [Interactive learning technology as an innovative pedagogical phenomenon.]. Ridna Shkola. Kyiv : Ridna Shkola, 2007. № 5. S. 46-49. (in Ukrainian)

4. Cysoieva, S.O. (2011). Interaktyvne navchannia doroslykh u systemi pisliadyplomnoi pedahohichnoi osvity [Interactive adult learning in the system of postgraduate pedagogical education]. Naukovi pratsi. Pedahohika. Vypusk 146. tom 158. Mykolaiv, 2011. S. 5-10. (in Ukrainian)

5. Skrypnyk, M.I. Interaktyvne navchannia: osnovni poniattia [Interactive learning: basic concepts]. Ihry doroslykh. Interaktyvni metody navchannia. Biblioteka. Kyiv: Red. zahalnoped. hazet, 2005. S. 30—44. (in Ukrainian)

\section{Михалюк А.М. \\ ИСПОЛЬЗОВАНИЕ ИНТЕРАКТИВНЫХ МЕТОДОВ ОБУЧЕНИЯ В ПРОЦЕССЕ ПОДГОТОВКИ БУДУЩИХ ПЕДАГОГОВ}

В статье отражена сущность интерактивных методов обучения и аргументировано преимущества их применения в образовательном процессе заведений высшего образования. Выявлены особенности использования интерактивных методов обучения в прочессе подготовки будущих педагогов. Дана характеристика отдельных методов интерактивного обучения, раскрыто значение их использования в прочессе формирования личностных и профессиональных качеств будущих педагогов. 
Ключевые слова: интерактивное обучение, методы интерактивного обучения; подготовка будущих педагогов.

\section{Mihalyuk A.}

PhD in Pedagogical Sciences, Senior Lecturer of Department of Theory and History of Pedagogy

Pedagogical Institute, Borys Grinchenko Kyiv University

\section{USE OF INTERACTIVE LEARNING METHODS}

\section{IN THE PROCESS OF PREPARATION OF FUTURE EDUCATORS}

In the article essence of interactive teaching methods is explained in the article and the advantages of their application in the educational process of higher education institutions are argued. The importance of the focus of the modern educational process not only on professional but also on personal growth of students is outlined. It is about the need to create condition for the formation of personality traits such as mobility, ability to integrate into a dynamic society, critical thinking, the ability to generate new ideas, the ability to make non-standard decisions and be responsible for them, communication skills, teamwork skills, skills educational situations, etc. The essence of interactive learning is defined, which consists in mutual learning, group form of organization of educational process with realization of active group teaching methods for solving didactic problems. The peculiarities of using interactive teaching methods in the process of preparation of future teachers are revealed. The essence of the most common interactive teaching methods is considered. Working in pairs is an effective method that involves sharing ideas with a partner and further voicing your thoughts to the audience. It is effective to use the Microphone method to update background knowledge, which enables each student to say something quickly, alternately, by answering questions or expressing their opinion or position. Collective discussion, such as Brainstorming, is at the forefront of the educational process of higher education. The Carousel method is most effective for simultaneously involving all participants in the educational process in active work with different partners to discuss discussion issues. The Learning-to-Learn method enables students to pass on their knowledge to their classmates. The method of projects that determines the acquisition and application of practical skills by students. An important tool for the cognitive activity of future professionals is a discussion that involves broad public discussion of some controversial issue. The role of interactive teaching methods in the process of formation of personal and professional qualities of future teachers is revealed.

Key words: interactive learning, methods of interactive learning; training of future teachers.

Стаття надійшла до редакції 12.04.2020

Прийнято до друку 17.04.2020 